\begin{tabular}{|c|c|c|c|c|}
\hline JURNAL & \multirow{2}{*}{ VOLUME 2} & \multirow{2}{*}{ NOMOR 1 } & HALAMAN 1-73 & $\begin{array}{l}\text { ISSN 2655-8823 }(p) \\
\text { ISSN 2656-1786 }(e)\end{array}$ \\
\hline
\end{tabular}

\title{
PERAN PENDAMPING DALAM PENGEMBANGAN USAHA KELOMPOK BINAAN PROGRAM KELUARGA HARAPAN (PKH) (Di Desa Lebakagung Kecamatan Karangpawitan Kabupaten Garut)
}

\author{
Putri Erika Ramadhani \\ Mahasiswa Prodi Kesejahteraan Sosial FISIP Unpad \\ E-mail:putri16012@mail.unpad.ac.id \\ Nandang Mulyana \\ Dosen Departemen Kesejahteraan Sosial FISIP Unpad \\ E-mail: mulyananandang@yahoo.com
}

\begin{abstract}
ABSTRAK
Penelitian ini adalah Peran Pendamping Dalam Pengembangan Usaha Kelompok Binaan Program Keluarga Harapan (PKH), di Desa Lebakagung, Kecamatan Karangpawitan, Kabupaten Garut. Pada tahun 2018 terdapat pendamping PKH yang berhasil mendapatkan dana dari Program Kelompok Usaha Bersama, dengan kelompok binaan yang beranggotakan 10 penerima manfaat, pendamping membuat kelompok untuk usaha E-Warung dan usahanya berjalan dari tahun 2008 sampai saat ini. Maka dari itu karena keberhasilan pendamping di Desa Lebakagung, penelitian ini bertujuan untuk mengetahui bagaimana bentuk pemberian peran pendamping dalam pengembangan usaha kelompok menggunakan konsep Ife \& Tesoreiro yaitu Peran dan Keterampilan Fasilitatif yang meliputi, animasi sosial, mediasi dan negosiasi, mengorganisir, memfasilitasi kelompok, pemanfaatan keterampilan dan sumber. Peran dan Keterampilan Edukasional yang meliputi, membangun kesadaran, memberikan informasi, dan pelatihan, lalu Peran dan Keterampilan Keterwakilan yang meliputi pencarian sumber daya, advokasi, hubungan public dan perwakilan public, dan jejaring, lalu yang terakhir Peran dan Keterampilan Teknis yang meliputi, manajemen dan control keuangan. Metode penelitian yang digunakan dalam penelitian ini adalah metode deskriptif dengan pendekatan kualitatif. Teknik pengumpulan data yang digunakan adalah indepth interview, observasi non partisipasi, dan studi dokumentasi. Informan dalam penelitian ini berjumlah tujuh orang yaitu satu orang dari Koordinator Kabupaten PKH Garut, satu orang dari Koordinator Kecamatan Karangpawitan, tiga orang pengurus inti usaha kelompok E-Warung, dan dua orang anggota kelompok E-Warung. Hasil dari penelitian ini yaitu pendamping telah memberikan Peran dan Keterampilan Fasilitatif, Edukasional, Keterwakilan dan Teknis. Hambatannya adalah terkait dengan kapasitas pendamping dalam membantu mengelola usaha, kebutuhan akan soft skills bagi pendamping perlu diperhatikan oleh penyelenggara PKH melalui pelatihan spesifik yang dikembangkan untuk pendamping. Maka Plan Of Treatment dalam penelitian ini mengadakan kegitan untuk meningkatkan kapasitas pendamping dalam membantu mengelola usaha.
\end{abstract}

Kata kunci: Program Keluarga Harapan (PKH) , Peran dan Keterampilan Pendamping, Program Kelompok Usaha Bersama (KUBE)

\section{PENDAHULUAN}

Dalam rangka percepatan penanggulangan kemiskinan sekaligus pengembangan kebijakan di bidang perlindungan sosial, Pemerintah Indonesia mulai tahun 2007 melaksanakan Program Keluarga Harapan (PKH). Dalam PKH, bantuan akan diberikan kepada Rumah Tangga Sangat Miskin (RTSM) dan sebagai imbalannya RTSM tersebut diwajibkan untuk menyekolahkan anaknya, melakukan pemeriksaan kesehatan termasuk pemeriksaan gizi dan imunisasi balita, serta memeriksakan kandungan bagi ibu hamil (Kementrian Sosial RI).

Salah satu program perlindungan sosial yang banyak disorot karena keberhasilannya dalam menurunkan tingkat kemiskinan adalah program conditional cash transfers (CCT). Laporan Fiszbein, Ariel dan Schady (2009) mengenai CCT menunjukkan bahwa: 


\begin{tabular}{|c|c|c|c|c|}
\hline JURNAL & \multirow{2}{*}{ VOLUME 2} & \multirow{2}{*}{ NOMOR 1 } & HALAMAN 1-73 & $\begin{array}{l}\text { ISSN 2655-8823 }(p) \\
\text { ISSN 2656-1786 }(e)\end{array}$ \\
\hline
\end{tabular}

Program $C C T$ di banyak negara telah berhasil membangun pelindung bagi rumah tangga miskin dari efek terburuk yang ditimbulkan dari pengangguran, sakit, atau guncangan pendapatan lainnya. Selain itu, $C C T$ pun berhasil memperbaiki tingkat partisipasi sekolah serta meningkatkan kunjungan penerima bantuan ke fasilitas kesehatan untuk pemeriksaan rutin dan penimbangan berat badan serta jadwal imunisasi bagi balita (Rawlings dan Rubio, 2003; Fiszbein, Ariel dan Schady, 2009).

Dalam pelaksanaan $\mathrm{PKH}$, tentunya dibutuhkan tenaga-tenaga untuk memperlancar pelaksaan PKH. Dibalik kelancaran pelaksaan misi atau tujuan PKH saat ini, terdapat sosok yang sangat luar biasa dalam melaksanakan amanah yaitu Pendamping PKH. Pendamping PKH adalah sumber daya manusia yang direkrut dan dikontrakkerjakan yang ditetapkan oleh Kementerian Sosial sebagai pelaksana pendampingan PKH. Keberhasilan PKH dipengaruhi oleh implementasi pemberdayaan masyarakat miskin dan peran pendamping. Menurut Banks (2003, hlm. 56) :

"Pada beberapa program sosial di negara-negara maju, keberadaan pendamping berhasil membantu meningkatkan dampak serta efektivitas program melalui intervensi, pemberian informasi serta pemberdayaan kepada penerima bantuan. Pendamping program berhasil menjembatani kebutuhan kelompok penerima bantuan program sosial tersebut."

Pendamping merupakan pihak kunci yang menjembatani penerima manfaat dengan pihak-pihak lain yang terlibat di tingkat kecamatan maupun dengan program di tingkat kabupaten/kota. Tugas dan tanggungjawab pendamping $\mathrm{PKH}$ secara umum adalah melaksanakan tugas pendampingan kepada RTSM/KSM peserta PKH. Selain tugas tersebut, pendamping juga berperan dalam pemberdayaan masyarakat miskin yang menjadi sasaran program.

Dalam program perlindungan sosial dengan pendekatan pendampingan sosial, pendamping $\mathrm{PKH}$ hadir sebagai agen perubah yang turut terlibat dalam menentukan keberhasilan kegiatan program di lapangan. Hal ini disebabkan oleh kenyataan bahwa secara teknis, para pendampinglah yang melaksanakan intervensi serta bersentuhan langsung dengan penerima manfaat PKH melalui berbagai peranan yang mereka tampilkan, terutama sejak pertemuan awal hingga proses pengaduan (Kemensos, 2011: 17).

Ritongga (2009) menyatakan bahwa:

Program pengentasan kemiskinan sebelum PKH yang dilakukan tanpa mekanisme pendampingan sosial dinyatakan kurang berhasil oleh beberapa pihak karena cenderung hanya berfokus pada upaya penyaluran bantuan sosial yang belum terintegrasi dan tidak bersifat memberdayakan bahkan dapat menyebabkan ketergantungan.

Pemberdayaan merupakan suatu hal yang penting dalam perkembangan kehidupan manusia. Hal ini karena saat ini masih banyak masyarakat Indonesia, khususnya masyarakat perdesaan yang tidak memiliki akses terhadap perkembangan teknologi dan sumberdaya sehingga mereka sulit untuk berkembang dan berdaya. Begitu pun dengan peserta PKH yang hanya berjalan administratif, mereka hanya bergantung kepada bantuanbantuan dari PKH.

Salah satu bentuk dari pemberdayaan itu sendiri ialah pemberdayaan masyarakat sebagai salah satu bentuk pengentasan kemiskinan dan peningkatan kesejahteraan masyarakat. Kegiatan pemberdayaan masyarakat memberi pandangan positif bahwa masyarakat miskin bukan hanya menerima bantuan secara langsung, akan tetapi juga dapat dibimbing untuk dapat 


\begin{tabular}{|c|c|c|c|c|}
\hline JURNAL & \multirow{2}{*}{ VOLUME 2 } & \multirow{2}{*}{ NOMOR 1 } & HALAMAN 1-73 & $\begin{array}{l}\text { ISSN 2655-8823 }(p) \\
\text { ISSN 2656-1786 }(e)\end{array}$ \\
KOLABORASI RESOLUSI KONFLIK
\end{tabular}

meningkatkan kapasitas diri guna meningkatkan taraf hidup.

Salah satu tugas pendukung pendamping yang dilaksanakan dalam Program Keluarga Harapan yaitu Meningkatkan kapasitas dan menumbuhkan semangat kemandirian dalam rangka pemberdayaan peserta pendamping $\mathrm{PKH}$ melalui Kelompok Usaha Bersama. Dimana tugas pendukung ini lebih menuntut kapasitas kemampuan pendamping dalam pelaksanaannya karena kegiatan yang dilakukan adalah memberdayakan atau meningkatkan kapasitas kelompok binaan PKH. Tugas pendamping yang lain seperti tugas pokok, tugas rutin, tugas pencatatan pelaporan, dan tugas pada penyaluran bantuan, hanya memastikan saluran bantuan sampai kepada target yang bersifat administratif.

Melalui kelompok binaan dengan program Kelompok Usaha Bersama (KUBE) bisa memberdayakan para peserta PKH dan membantu mereka selain menerima bantuan dari PKH. Peserta PKH harus bisa keluar dari kemiskinan dan tidak bergantung pada bantuan administratif $\mathrm{PKH}$ sehingga harus ada aktivitas ekonomi dengan kelompok usaha ini. Dengan adanya peran pendamping dalam pengembangan usaha kelompok binaan, di Desa Lebak Agung terdapat pendamping PKH yang berhasil mengembangkan usaha kelompok binaanya melalui Kelompok Usaha Bersama dengan mengajukan proposal hingga mendapatkan dana dari program KUBE, usaha yang dikerjakan yaitu cikal bakal dari toserba mini yang menyediakan sembako seperti beras, telur, terigu, gula dan kebutuhan rumah tangga lainnya dan juga ada perlengkapan alat-alat sekolah anak-anak.

Pendamping di Desa Lebak Agung mendapat penghargaan menjadi duta pendamping di tingkat Kabupaten, karena peran yang dilakukannya dalam pengembangan kelompok binaan melalui kelompok usaha bersama yang berjalan selama 2 tahun, kelompok usaha nya yaitu
E-Warung. Peran yang dilakukan pendamping berkaitan dengan Peran dan Keterampilan menurut Ife dan Tesoreio yaitu Peran dan Keterampilan Fasilitatif, Peran dan Keterampilan Keterwakilan, Peran dan Keterampilan Teknis. Sedangkan di Desa yang lain di Kecamatan Karangpawitan ada juga yang menerima bantuan dana dari KUBE untuk usaha dibidang Ternak Domba tetapi dalam jarak kurang dari 1 tahun bangkrut, hewan ternak mati. Ada juga yang sudah mengajukan proposal usaha tetapi ditolak karena tidak memenuhi syarat KUBE.

Berdasarkan pada berbagai ulasan mengenai peran seorang pendamping dalam Program Keluarga Harapan (PKH) dalam pengembangan usaha kelompok binaan, meskipun dengan adanya peran pendamping sudah dinyatakan telah berhasil tetap harus ditingkatkan agar kualitas setiap pendamping di PKH semakin baik dan benar-benar menjalankan kewajiban sebagai pendamping $\mathrm{PKH}$ dan menjalankan tugastugasnya dari mulai tugas pokok, tugas pendukung dan tugas penunjang, dengan tujuan demi meningkatkan kapasitas RTSM dalam kelompok binaannya. Dalam rangka melaksanakan tugasnya, Pendamping $\mathrm{PKH}$ harus terlibat aktif dalam menjalin komunikasi dan koordinasi serta membangun kemitraan dengan unsurunsur di luar kelembagaan PKH dan atau dengan unsur berbasis masyarakat. Dengan demikian penelitian ini dilakukan demi tujuan hal tersebut.

\section{METODE PENELITIAN}

Penelitian ini bermaksud untuk memahami dan menjelaskan Peran Pendamping Dalam Pengembangan Usaha Kelompok Binaan Program Keluarga Harapan. Oleh karena itu hasil yang di dapatkan nantinya akan berbentuk deskripsi. Artinya bahwa penelitian ini tidak membutuhkan data berbentuk angka namun berupa narasi, cerita, catatan lapangan, dokumen tertulis dan tidak tertulis (gambar atau foto). Maka, Metode 


\begin{tabular}{|c|c|c|c|c|}
\hline JURNAL & \multirow{2}{*}{ VOLUME 2 } & \multirow{2}{*}{ NOMOR 1 } & HALAMAN 1-73 & $\begin{array}{l}\text { ISSN 2655-8823 }(p) \\
\text { ISSN 2656-1786 }(e)\end{array}$ \\
\hline
\end{tabular}

ini digunakan untuk memperoleh informasi mengenai suatu gejala atau suatu kejadian saat melakukan penelitian di Desa Lebakagung dan bertujuan untuk mendeskripsikan peran pendamping dalam pengembangan usaha kelompok binaan PKH.

Adapun alasan peneliti menggunakan pendekatan penelitian kualitatif adalah untuk mencari dan memahami potensi pemecahan masalah secara mendalam berdasarkan fakta langsung di lapangan. Dengan pendekatan kualitatif peneliti juga dapat melihat langsung kondisi lapangan secara komprehensif mengenai peran pendamping dalam pengembangan usaha kelompok binaan PKH di Desa Lebak Agung.

Dalam penelitian ini menggunakan teknik penelitian indepth interview, observasi non-partisipatif, studi dokumentasi. Informan yang dipilih pada penelitian ini adalah satu orang dari Koordinator Kabupaten PKH Garut, satu orang dari Koordinator Kecamatan Karangpawitan, tiga orang pengurus inti usaha kelompok E-Warung, dan dua orang anggota kelompok E-Warung. Adapun instrument pengumpulan data yang akan digunakan dalam penelitian ini adalah pedoman wawancara, pedoman observasi, dan alat bantu yang digunakan yakni perekam suara dan kamera untuk mendokumentasikan hal yang dianggap penting untuk meunjang data-data penelitian. Untuk pengolahan data dan analisis data terdapat tiga langkah pengolahan data kualitatif yaitu reduksi data, penyajian data dan penarikan kesimpulan serta verifikasi data.

\section{HASIL DAN PEMBAHASAN}

\section{a. Peran dan Keterampilan Fasilitatif}

Hasil di lapangan yang diperoleh penulis melalui observasi dan wawancara kepada informan adalah usaha kelompok E-Warung ini memfasilitasi anggota kelompok untuk meningkatkan kapasitas dan juga membantu mendapatkan pendapatan untuk setiap anggota kelompok. Peran fasilitatif sangat penting dilakukan oleh pendamping karena membangkitkan semangat kelompok dalam mengelola usaha, menerapkan pemahaman untuk pengembangan diri, memusyawarahkan keputusan yang akan dilakukan oleh pendamping dan kelompok secara bersama-sama untuk mempermudah dalam mengelola usaha dan berproses untuk mencapai tujuan usaha. Peran dan keterampilan fasilitatif meliputi animasi sosial, mediasi dan negosiasi, mengorganisir, memfasilitasi kelompok, pemanfaatan keterampilan dan sumber.

Dalam menjalankan peran fasilitatif pendamping memberikan keterampilan animasi sosial yaitu memberikan dorongan semangat kepada kelompok EWarung pada saat pengelolaan usaha, pendamping memberikan semangat kepada anggota kelompok dengan bantuan dari Ketua kelompok usaha EWarung untuk memberikan motivasi dan mengingatkan tujuan awal untuk membuat E-Warung menjadi Toserba mini. Juga memberi dukungan dan motivasi kepada anggota kelompok yang merasa tidak percaya diri dalam mengelola usaha dan mengembangkan keterampilannya dalam usaha, pendamping dan juga anggota kelompok lain bekerja sama agar menjaga hubungan baik antar anggota kelompok E-Warung dan saling mendukung untuk meningkatkan kapasitas atau keterampilan di kelompok usaha EWarung, dan juga harus menjaga hubungan baik yang sudah terjalin dengan konsumen dan mitra-mitra yang bekerjasama dan mendukung usaha EWarung, dengan tidak mengecewakan.

Untuk keterampilan mediasi dan negosisasi, pendamping mengatakan bahwa di dalam kelompok E-Warung ini pernah terjadi konflik karena ketidakpuasan hasil kerja satu sama lain, seperti contohnya pada saat pengemasan produk Telur, tidak berhati-hati lalu telur sampai pecah karena ceroboh, timbul 


\begin{tabular}{|c|c|c|c|c|}
\hline JURNAL & \multirow{2}{*}{ VOLUME 2 } & \multirow{2}{*}{ NOMOR 1 } & HALAMAN 1-73 & $\begin{array}{l}\text { ISSN 2655-8823 }(p) \\
\text { ISSN 2656-1786 }(e)\end{array}$ \\
\hline
\end{tabular}

konflik antar anggota sehingga pendamping perlu menjadi mediator di dalam kelompok, informasi yang didapat oleh penulis pendamping memang sudah dipercaya oleh kelompok E-Warung sebagai seseorang yang berpihak atau berwenang memiliki andil dalam proses mediasi dan negosiasi yang terjadi di dalam kelompok maupun diluar kelompok.

Selanjutnya informasi yang peneliti dapatkan yaitu dari Koordinator Kabupaten, yang mengatakan bahwa pendamping itu memang yang memberikan dukungan dan membantu mediasi di dalam kelompok atau di luar kelompok, tetapi pendamping tidak lebih dari itu, karena yang harus mengelola dan mempertahankan usaha E-Warung adalah kelompoknya, pendamping hanya membantu untuk mengontrol dan memberi saran kepada kelompok, dan yang betul-betul turun di lapangan usaha E-Warung adalah penerima manfaat yang termasuk dalam kelompok usaha bersama.

Adapun informasi yang peneliti dapatkan dari salah satu Anggota kelompok E-Warung mengatakan bahwa mereka membagi jadwal untuk setiap harinya bergantian menjaga E-Warung, disisi lain setiap yang menjaga warung mereka anggota kelompok E-warung dan juga atas perundingan dengan pendamping akhirnya sepakat untuk memberikan upah sebesar 10.000 ribu rupiah setiap kali jaga dari hasil keuntungan E-Warung, dan dengan adanya metode itu para anggota kelompok semakin bersemnagat untuk selalu mengelola E-Warung dan terus melatih keterampilan mereka dalam mengelola usaha kelompok E-Warung.

Dalam menjalankan keterampilan mengorganisir, pendamping membantu membuat kelompok usaha, ketika kelompok sudah terbentuk pendamping dan semua anggota berkumpul di salah satu rumah penerima manfaat anggota kelompok E-Warung untuk bermusyawarah menentukan struktur kepengurusan E-Warung. Pertama, pendamping menentukan siapa yang akan menjadi ketua, lalu sekretaris dan bendahara, setelah pengurus inti sudah terpilih sesuai dengan persetujuan seluruh anggota kelompok, pendamping membantu membagikan jobdesk untuk anggota kelompok E-Warung seperti, pengemasan, sortir barang, memastikan barang dari Grosir.

Lalu untuk pemanfaatan keterampilan dan sumber, pada saat mencari penerima manfaat yang akan bergabung dalam kelompok E-Warung, pendamping memperhatikan setiap penerima manfaat yang pada dasarnya pernah menjadi pedagang yang diutamakan untuk bergabung dalam kelompok E-Warung, tetapi tidak semua anggota mempunyai keterampilan tersendiri. Dan untuk pemanfaatan sumber di sekitar wilayah Desa Lebakagung pendamping bekerja sama dengan petani beras untuk memasok produk beras di E-Warung. Dengan begitu pendamping dapat menjalankan keterampilannya dalam memfasilitasi kelompok melalui EWarung ini, penerima manfaat dapat meningkatkan kapasitasnya secara mandiri atau pun dengan kelompok, dan berpengalaman dalam mengelola usaha khususnya E-Warung.

\section{b. Peran dan Keterampilan Edukasional}

Peran Edukasional sangat penting dilakukan oleh pendamping karena berperan aktif dalam memberikan masukan dalam rangka untuk peningkatan pengetahuan dan keterampilan serta berbagi pengalaman terhadap setiap anggota kelompok.Terkait dengan peran edukasional / mendidik pendamping melakukan keterampilan yaitu membangun kesadaran dan memberikan informasi juga pelatihan pada kelompok E-Warung, informasi yang peneliti dapatkan ketika terjun langsung ke 


\begin{tabular}{|c|c|c|c|c|}
\hline JURNAL & \multirow{2}{*}{ VOLUME 2} & \multirow{2}{*}{ NOMOR 1 } & HALAMAN 1-73 & $\begin{array}{l}\text { ISSN 2655-8823 }(p) \\
\text { ISSN 2656-1786 }(e)\end{array}$ \\
\hline
\end{tabular}

lapangan adalah pendamping membangun kesadaran penerima manfaat dengan memberikan infromasi kepada kelompok E-Warung mengenai pengelolaan usaha dan pendamping memberikan motivasi kepada penerima manfaat agar senantiasa mampu melaksanakan pengembangan diri atau mengasah kemampuan mereka. Bentuk kegiatan yang dilakukan oleh pendamping guna memberikan informasi yang bermanfaat kepada penerima manfaat di kelompok E-Warung, berupa kegiatan penyuluhan atau sosialisasi mengenai pengelolaan usaha untuk EWarung, sosialisasi dari pengelolaan usaha tersebut meliputi pengetahuan dan informasi mengenai cara manajemen usaha, membuat Laporan Penanggungjawab keuangan usaha, menghitung arus kas, estimasi harga barang.

Penyuluhan atau sosialisasi ini memang belum ada program yang rutin dilakukan, pendamping hanya menyampaikan informasi tersebut hanya dengan anggota kelompok dan tampat pelaksanaannya yaitu di E-Warung. Menurut informasi yang peneliti dapatkan dilapangan yaitu dari Koordinator Kabupaten, pendamping mendapatkan pelatihan khusus bagi yang memegang kelompok usaha bersama (KUBE) yang diselenggarakan oleh Kementrian Sosial, disana pendamping mendapatkan informasi mengenai apa usaha itu, bagaimana mengelola usaha dan juga mengontrol keuangan, pendamping yang mengikuti pelatihan ini membutuhkan waktu sekitar 460 jam lamanya dan kegiatan pelatihan berlangsung di Lembang Bandung atau di Yogyakarta. Lalu pelatihan ini sejak 2016 belum pernah diadakan lagi oleh Kementrian Sosial, maka dari itu pendamping yang mempunyai kelompok usaha harus mempunyai jiwa usaha dan juga rasa ingin tahu yang tinggi untuk mencari tahu setiap strategi dan progress yang akan dilakukan dalam setiap pengelolaan kelompok usaha, juga sangat dibutuhkan kerjasama yang baik antara pendamping dan kelompok supaya tidak terjadi kegagalan dalam usaha E-Warung.

Menurut Ketua kelompok dari EWarung, pendamping sangat memberikan informasi dan memberikan pelatihan yang bermanfaat bagi penerima manfaat di kelompok, dari yang tidak paham menjadi paham, dari yang tidak bisa menjadi terbiasa, seperti halnya dalam menuliskan pembukuan arus kas, pembuatan LPJ, pengemasan produk, sebagian penerima manfaat dalam kelompok tidak ada yang mempunyai keterampilan untuk hal-hal seperti itu sebelumnya, dan dengan adanya pendamping kelompok sangat terbantu untuk mendapatkan pengetahuan dan keterampilan baru yang harus mereka jalani dan itu yang akan menjadi bekal mereka untuk mengelola usaha dan berdiri diatas kaki mereka sendiri nantinya. Dan juga Ketua Kelompok EWarung mengharapkan adanya sosialisasi atau penyuluhan yang melibatkan pihak lain seperti mendengarkan tips dan caracara mengelola usaha dari seorang pengusaha besar, menurut mereka itu akan menjadi motivasi tambahan juga untuk kelompok supaya mendapatkan pengetahuan seluas mungkin dalam pengelolaan usaha.

Menurut penuturan dari Koordinator Kecamatan, kelompok usaha di Desa Lebakagung memang belum pernah mengadakan pelatihan yang mendatangkan pihak yang berkaitan dengan usaha karena beberapa hal seperti letak Desa Lebakagung yang agak terpencil dan tranportasi umum yang sulit, penentuan waktu dan situasi kondisi yang belum tepat untuk menyelenggarakan pelatihan karena harus disesuaikan dengan jadwal kegiatan dari PKH agar tidak berbentur, juga menyesuaikan dengan waktu narasumber. 


\begin{tabular}{|c|c|c|c|c|}
\hline JURNAL & \multirow{2}{*}{ VOLUME 2} & \multirow{2}{*}{ NOMOR 1 } & HALAMAN 1-73 & $\begin{array}{l}\text { ISSN 2655-8823 }(p) \\
\text { ISSN 2656-1786 }(e)\end{array}$ \\
\hline
\end{tabular}

\section{c. Peran dan Keterampilan Keterwakilan}

Peran keterwakilan sangat penting dilakukan pendamping guna melakukan interaksi dengan pihak eksternal untuk kepentingan internal (kelompok usaha) mencari dan mendapatkan modal usaha, membuka jaringan kerja dari pihak Grosir/toko buku dengan E-Warung, mendorong kelompok untuk selalu berpartisipasi dalam pengembangan potensi diri. Keterampilan yang dilakukan oleh pendamping yaitu pencarian sumber daya, advokasi, hubungan public dan perwakilan public, dan jejaring. Dalam hal ini peneliti mendapatkan informasi mengenai peran dan keterampilan keterwakilan yang dilakukan pendamping pada saat pengembangan kelompok usaha E-Warung. Pada saat awal terbentuknya kelompok usaha E-Warung ini, pendamping dan kelompok mulai mencari sumberdaya atau potensi di Desa Lebakagung yang akan mendukung usaha E-Warung, seperti apa saja barang dan produk yang akan tersedia dan dijual di EWarung, pendamping dan kelompok mulai bermitra dengan salah satu petani beras di Desa Lebakagung untuk memasok beras nantinya di E-Warung, juga pendamping mencari kerjasama di luar Desa Lebakagung dengan grosir barang-barang sembako seperti minyak, mie, sabun cuci, terigu, telur dan lainlain. Sehingga jika terdapat banyak sumber yang mendukung dan banyaknya mitra yang bekerja sama dengan E-warung, usaha ini berkembang dan mempunyai banyak mitra kerja sama untuk pemasukan barang di E-warung. Sampai saat ini E-Warung telah mempunyai 4 mitra kerja sama yaitu Grosir, petani beras, penjual telur, dan toko buku tulis anak sekolah di Garut.

Dengan berjalannya usaha E-Warung sejak 2018 ini menurut penuturan Koordinator Kecamatan kelompok usaha E-Warung ini telah menjadi ikon kelompok usaha yang bertahan di Kabupaten Garut, karena keberhasilan pendamping dalam menemukan potensi dan menggerakan penerima manfaat di dalam kelompok usaha, penerima manfaat yang termasuk dalam kelompok usaha pun berhasil bertahan, mengembangkan potensinya di kelompok untuk mengelola usaha ini dari tahun 2018 sampai saat ini. Karena hal itu menurut penuturan pendamping penerima manfaat yang bergabung dalam kelompok usaha Ewarung pun sangat senang dan semakin meningkat lagi semangat dan antusias untuk mengembangkan usahanya. Pendamping dan kelompok pun sering melakukan pemasaran di lingkungan Desa Lebakagung mengajak untuk berbelanja di E-warung, tetapi untuk mempromosikan atau memasarkan lewat media sosial belum terpikirkan oleh pendamping dan kelompok.

Lalu informasi yang peneliti dapatkan pada saat dilapangan adalah terkait dengan pemberian advokasi oleh pendamping terhadap penerima manfaat yang berkonflik atas nama invidu atau kelompok E-Warung baik itu di dalam kelompok maupun diluar kelompok. Dalam kelompok usaha diantara anggota memang selalu terjadi konflik tetapi bisa diselesaikan secara baik-baik dan kekeluargaan karena konflik yang terjadi hanya berkaitan dengan kurang puas atas hasil kerja dari setiap anggota seperti halnya ada kecerobohan dalam pengemasan barang telur karena tidak benar dalam pengemasannya telur pecah yang mengakibatkan kerugian terjadilah konflik. Menurut penuturan Koordinator Kabupaten, selama di Kabupaten Garut terdapat pendamping dan penerima manfaat yang merima bantuan dan membentuk KUBE tidak pernah terjadi masalah serius yang harus melibatkan pihak berwajib. Masalah dari KUBE tersendiri yang sering terjadi karena ketidakberhasilan KUBE dan Laporan Penanggungjawaban yang tidak tepat.

\section{d. Peran dan Keterampilan Teknis}

Peran Teknis sangat penting dilakukan oleh pendamping karena dapat 


\begin{tabular}{|c|c|c|c|c|}
\hline JURNAL & \multirow{2}{*}{ VOLUME 2 } & \multirow{2}{*}{ NOMOR 1 } & HALAMAN 1-73 & $\begin{array}{l}\text { ISSN 2655-8823 }(p) \\
\text { ISSN 2656-1786 }(e)\end{array}$ \\
KOLABORASI RESOLUSI KONFLIK
\end{tabular}

memberikan informasi kepada kelompok terkait penggunaan computer/laptop untuk pengerjaan Laporan Pertanggung Jawaban, dapat melakukan presentasi verbal dalam menyampaikan kemajuan usaha E-Warung, mengelola manajemen dan keuangan usaha, sehingga menjadikan kelompok paham dan terbiasa mengerjakan kegiatan mengelola usaha. Dalam peran teknis pendamping melakukan keterampilan manajemen dan control keuangan pada kelompok EWarung. Informasi yang peneliti dapatkan mengenai peran teknis yang dilakukan pendamping terhadap usaha kelompok E-Warung adalah membantu menerapkan manajemen usaha seperti pada saat membuat laporan penangungjawaban E-Warung pendamping memberikan contoh bagaimana membuat LPJ dan data apa saja yang dibutuhkan dalam LPJ EWarung tersebut, pendamping selalu mengontrol kelompok ketika dalam penngerjaan LPJ dan memeriksa jika terdapat kesalahan, pendamping mengajarkan Sekretaris kelompok bagaimana cara penggunaan computer atau laptop karena itu yang akan menjadi rutinitas kelompok untuk membuat LPJ dan supaya terbiasa akan hal-hal yang pengerjaannya memakai computer/laptop.

Menurut penuturan Sekretaris EWarung, dengan adanya sharing session dengan pendamping, memudahkan anggota kelompok E-Warung dalam pengerjakan setiap jobdesc yang sudah diberikan pada masing-masing anggota sama halnya seperti membuat LPJ semakin terbiasa dan untuk membuat pembukuan arus kas, mencatat sortir barang, melakukan pengemasan produk, sampai saat ini pendamping hanya mengontrol kelompok jika ada kesalahan yang tidak kelompok sadari. Dalam hal teknis, kelompok E-Warung sudah terbiasa akan mengelola usaha dan menjaga hubungan berkomunikasi baik dengan mitra yang bekerja sama dengan E-Warung, pendamping tetap selalu mengontrol kelompok dalam jangka waktu sekali dalam 1 minggu.

\section{KESIMPULAN DAN SARAN Kesimpulan}

Penelitian ini menganalisis peran pendamping $\mathrm{PKH}$ dengan menggunakan peran pekerja komunitas yang dikembangkan oleh Ife dan Tesoriero dalam pengelolaan da pengembangan usaha. Hasil dari penelitian ini menunjukkan bahwa pendamping memainkan peran fasilitatif, edukasional, keterwakilan dan teknis dalam pegembangan usaha kelompok bersama.

Peran fasilitatif yang dilakukan pendamping selama pengelolaan dan pengembangan usaha meliputi peran animasi sosial, mediasi, mengorganisir, memfasilitasi kelompok, membangun komunikasi personal, serta pemanfaatan keterampilan. Namun demikian, masih terdapat konflik diantara anggota kelompok karena ketidakpuasan dari hasil kerja masing-masing anggota mengenai pengelolaan usaha kelompok.

Beberapa peran yang dipraktikkan oleh pendamping dalam peran edukasional meliputi peran membangun kesadaran, pemberian informasi, serta untuk menyelenggarakan pelatihan. Dalam menjalankan perannya, sikap dan karakter dari setiap anggota yang berbeda-beda maka pendamping bekerja sama dengan Ketua kelompok untuk membangun kesadaran dan memotivasi mereka. Selain itu, pendamping belum sempat menyelenggarakan memberikan penyuluhan atau pelatihan kepada kelompok dengan mendatangkan pihak lain yang menggeluti bidang usaha atau bisnis. Selama ini hanya memberikan pelatihan dan menyampaikan informasi terkait pengelolaan usaha, seperti pembukuan, pengemasan, pengelolaan barang, pengelolaan arus kas, pembuatan laporan penanggungjawaban usaha kelompok.

Peran keterwakilan yang pendamping lalukan dalam pengelolaan dan 


\begin{tabular}{|c|c|c|c|c|}
\hline JURNAL & \multirow{2}{*}{ VOLUME 2 } & \multirow{2}{*}{ NOMOR 1 } & HALAMAN 1-73 & $\begin{array}{l}\text { ISSN 2655-8823 }(p) \\
\text { ISSN 2656-1786 }(e)\end{array}$ \\
\hline
\end{tabular}

pengembangan usaha antara lain pencarian sumber daya, advokasi, membangun jejaring serta hubungan public dan perwakilan publik. Pendamping bersama anggota kelompok usaha E-Warung berhasil mencari sumber daya yang dibutuhkan dalam kelompok usaha dan juga dapat bekerja sama dengan pihak yang berperan penting untuk memasok barang secara rutin di E-Warung. Dalam hal advokasi pendamping belum pernah menangani masalah yang serius harus melibatkan pihak berwajib, hanya sebatas masalah di dalam kelompok dan dapat terselesaikan secara musyawarah.

Dalam peran dan keterampilan teknis presentasi verbal dan lisan adalah dua keterampilan yang dimainkan pendamping dalam pengelolaan dan pengembangan usaha. Peran ini ditemui pada setiap tahapan menyampaikan juga mengarahkan dalam proses manajemen usaha, pengelolaan usaha, keuangan usaha lalu pembuatan laporan pertanggungjawaban usaha dengan anggota kelompok EWarung. Tantangan yang dihadapi pendamping dalam peran teknis ini berhubungan dengan ketelitian anggota kelompok yang menjalankan teknis usaha, sehingga dalam pelaksanaannya pendamping harus selalu aktif untuk mengawasai setiap langkah yang mereka jalani.

\section{Saran}

Peran Pendamping dalam pengelolaan usaha kelompok di Desa Lebakagung, Kecamatan karangpawitan, Kabupaten Garut masih terdapat hambatan sehingga penulis memberikan saran antara lain:

1. Bagi Pendamping PKH

Dalam upaya meningkatkan kapasitas pendamping untuk membantu mengelola usaha kelompok. Kebutuhan akan soft skills bagi pendamping perlu diperhatikan oleh penyelenggara Program Keluarga Harapan melalui pelatihan spesifik yang dikembangkan untuk pendamping.
2. Bagi Penyelenggara PKH

Keempat peran dan keterampilan yang dikelmukakan oleh ife \&tesoreiro yang terkait erat dengan pekerjaan pendamping perlu ditambahkan ke dalam modul pelatihan, yang meliputi peran dan keterampilan fasilitatif, peran dan keterampilan edukasional, peran dan keterampilan keterwakilan, peran dan keterampilan teknis.

3. Bagi penerima manfaat kelompok usaha

Selain lebih meningkatkan lagi kemampuan pendamping, juga harus menyelenggarakan pelatihan keterampilan secara spesifik dan intensif kepada anggota kelompok dengan mendatangkan pihak yang menjalankan usaha, agar peningkatan kelompok usaha lebih diarahkan lagi khususnya dalam hal sistem teknis, manajemen usaha, pengelolaaan arus kas, laporan pertanggungjawaban, pengetahuan tentang pembukuan yang akuntable dan tranparansi, serta pola pemasaran.

\section{DAFTAR PUSTAKA}

ADB. (2008). The Pro Poor Planning and Budgeting Project. Working Paper No.5: Program Keluarga Harapan (PKH): Two Case Studies in Implementing the Indonesian Conditional Cash Transfer Program. Jakarta: Hickling.

Bloom, \& Schelzig, K. (2009). Conditional Cash Transfer: Lessons from Indonesia's Program Keluarga Harapan. Rapat rutin Bappenas. Jakarta.

Conny R, S. (2010). Metode Penelitian Kualitatif. Jakarta: Grasindo.

Haryanto. (2009). Diklat Rehabilitasi dan Pekerjaan Sosial Universitas Yogyakarta.

Hermawati, I. (2001). Metode dan Teknik Dalam Praktik Pekerjaan Sosial. Yogyakarta: Adicita Karya Nusa. 


\begin{tabular}{|c|c|c|c|c|}
\hline JURNAL & \multirow{2}{*}{ VOLUME 2 } & \multirow{2}{*}{ NOMOR 1 } & HALAMAN 1-73 & $\begin{array}{l}\text { ISSN 2655-8823 }(p) \\
\text { ISSN 2656-1786 (e) }\end{array}$ \\
KOLABORASI RESOLUSI KONFLIK
\end{tabular}

Huraraerah, A. (2011). pengorganisasian dan pengembangan masyarakat. model strategi pembangunan berbasis kerakyatan. bandung: humaniara.

Ife, J., \& Tesoriero, F. (2008). Community Development: Alternatif Pengembangan Masyarakat di Era Globalisasi. Yogyakarta: Pustaka Pelajar.

J, D. N., \& Suyanto. (2013). Sosiologi Teks Pengantar Dan Terapan. Jakarta: Kencana.

Kartasasmita, G. (1995). Pemberdayaan Masyarakat.

Nelfina. (2009). Etika Profesi Pekerjaan Sosial. Padang: Depsos RI.

No.10/HUK/2007, K. M. (2007). Pedoman Pembinaan Teknis Jabatan Fungsional Pekerja Sosial. Jakarta.

RI, K. S. (2011). Buku Petunjuk Pelaksanan Program PKH. Jakarta: KemensosRI.

Rukminto, A. I. (2002). Pemikiranpemikiran dalam Pembangunan Kesejahteraan Sosial. Jakarta: Lembaga Penerbitan FEUI.

Rustanto, B. (2002). Model Pengembangan Masyarakat Melalui Forum warga peduli. Jakarta: YPM Kesuma.
Rustanto, B. (2006). Kearifan Lokal dan Gerakan Sosial, Pelayanan Sosial Berbasis Masyarakat. Bandung: STKS Press.

Rustanto, B. (2015). Membangun Organisasi dalam Pemberdayaan Masyarakat Miskin. Bandung: STKS Press.

Sarlito, S. W. (2007). Teori-Teori Psikologi Social. 214-215.

Soetomo. (2008). Masalah Sosial dan Upaya Pemecahannya. Yogyakarta: Pustaka Pelajar.

Sosial, D. (2003). Kebijakan Operasional Pemberdayaan Wahana Kesejahteraan Sosial Berbasis Masyarakat (WKSBM). Jakarta: Departemen Sosial.

Sosial, D. J. (2015). Buku Kerja Pendamping dan Operator PKH. Jakarta: Kemensos RI.

Suharto, E. (2007). Pekerja Sosial di Dunia Industri. Bandung: Alfabeta.

Suharto, E. (2015). Membangun Masyarakat Memberdayakan Rakyat: Kajian Strategi Pembangunan Kesejahteraan Sosial dan Pekerjaan Sosial. Bandung: Refika Aditama.

Wibhawa, B., T.R, S., \& B.S, M. (2010). Dasar-Dasar Pekerjaan Sosial. Bandung: Widya Padjadjaran. 